\title{
Some Trivial Technical Fatal Errors in Medical Decision-Making Occur in Every Hospital Almost Every Month
}

\author{
Antonín Cuc* \\ The International expert in occupational Health and Safety, Czech Technical University, Czech Republic
}

Submission: March 17, 2018; Published: April 09, 2018

*Corresponding author:Antonín Cuc, The International expert in occupational Health and Safety, Czech Technical University, Na Mícánkách 435/1,101 00 Prague 10, Czech Republic, Europe, Email: betruea@gmail.com

\section{Opinion}

In 2010, the Czech Republic participated in the global relative frequency of medical errors in decision-making and diagnostics and in choosing the right individual choice of treatment for a particular patient. It has been found worldwide and for all types of outpatient and hospitalization services and across all medical care sectors - that of major mistakes in diagnosis or choice of treatment - have a relative frequency of occurrence by default accuracy of the statistical range of $+/-2 \%$, with $95 \%$ statistic reliability!: On the website of the Ministry of Health of the Czech Republic, it was explicitly stated - that it is often a substitution of a disease between different patients, or surgical surgery was performed on the wrong paired organ of the patient - for example, by replacing the right or left lower limb with the replacement of the right or left kidney patient, or using a postoperative infusion with inappropriate composition between the two different patients in the bed part of the orthopaedic clinic, or the surgery was performed on the wrong pulmonary lobe.

I am very horrified when most doctors of the Czech Republic consider such a medical disaster for a patient for a medical practice in compliance with the principles of "LEGE ARTIS CZ" and furthermore argue that such a miserable "small technical medical mistake" does not occur more often than approximately once a month ... and that they will not feel the potential consequences of the mutilation or causal previous death at all. Since doctors and nurses are very few in hospital, the doctors are working over many hours of overtime - often they do not even have their full hours worked by the employer ... so that these errors can mainly be funded by the network of hospitals in the Czech Republic, doctors on the Czech labour market, etc.

Damaged patients in the Czech Republic will never receive a fair Court trial with justified Criminal evidences, a fair assessment of the responsibility of some doctors and Employers will never receive adequate compensation for the permanent destruction of Patient health and a much earlier enforced death. As an expert in Cybernetics and an analyst of decision-making with risk, I really wonder - why is the health service so permanently and totally misplaced the work and responsibility of doctors, technicians, computer support ... because if doctors in hospitals CZ are wrong with the average risk of a particular repeated mistake ... for example, the replacement of the frequency a mistakes: 1/500 patient's different Patient Health record - it is not a problem for cyber security planners to operate in a nuclear power plant to completely eliminate a similar error with a probability of at least relative statistic guaranted frequency $1 / 10$ million - otherwise, our atomic plants of the Czech Republic's power plants - Of the Czech Republic ... and in case of 1 Mistake -there was casual no one to cure or treat.

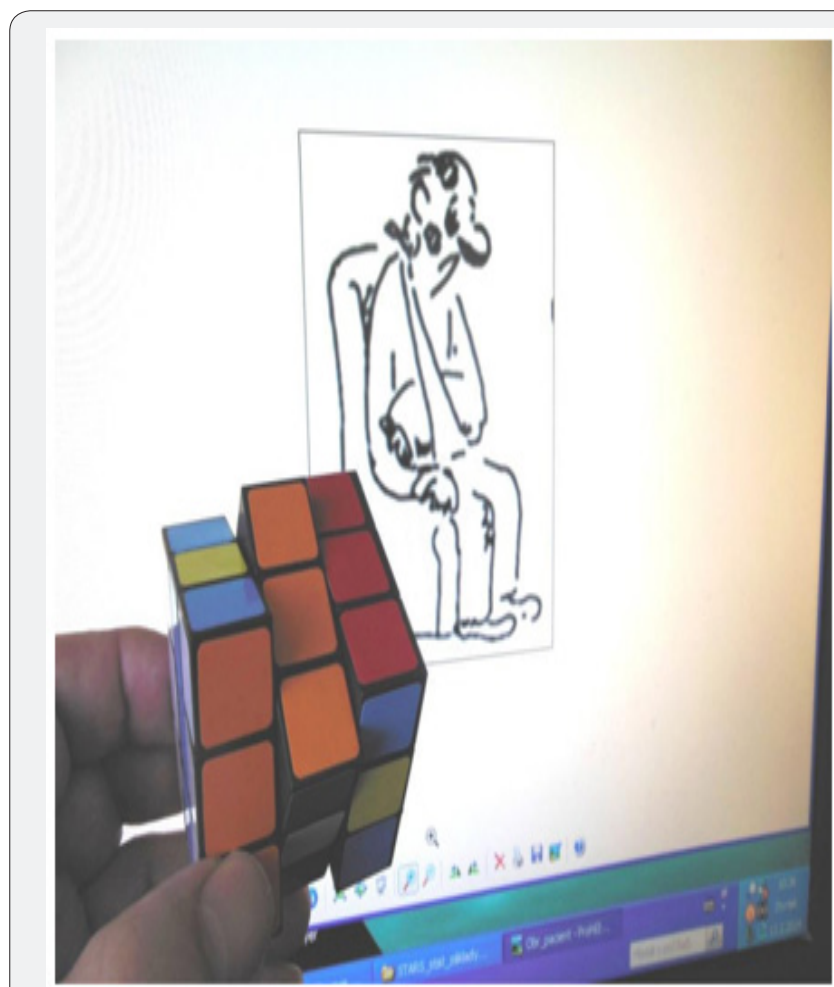

Figure 1 
I consider it unforgivable the boldness of the existing occupational safety system in the Czech hospitals that the doctors in these operations behave like non-criminalizing demigods ... although the concentration of all rights and the concentration of all decision-making responsibilities leave them in their ethically and technically completely irresponsible hands to all cards and their tricks are constantly on the ground as if they were to petrify their stupidity and technical backwardness 80 years after the start of the industrial revolution in the field of Mass aviation and safety super visiting the Aerospace, in the field of computers and electric power production in the nuclear power plants working in the Czech Republic continually. As an Expert in Cybernetics and as I am too a now freeze and needless dying patient CZ - I have a surprising wonder and a silent question about my contemplative thinking readers in medical US journals - why are not you overwhelmed by such overcome ways of doing continual false illegal medical work in the Czech Republic and..... In the worldwide? (Figure 1).

\section{The Contextual and use Literature}

Antonín Cuc, The Utility model 21532 CZ 2010 - The Equipment for Statistical Retrieval and Search of sufficient information to Mas reuse for similar strategic decision making with risk and computer support.

\section{Your next submission with Juniper Publishers will reach you the below assets}

- Quality Editorial service

- Swift Peer Review

- Reprints availability

- E-prints Service

- Manuscript Podcast for convenient understanding

- Global attainment for your research

- Manuscript accessibility in different formats ( Pdf, E-pub, Full Text, Audio)

- Unceasing customer service

Track the below URL for one-step submission https://juniperpublishers.com/online-submission.php 